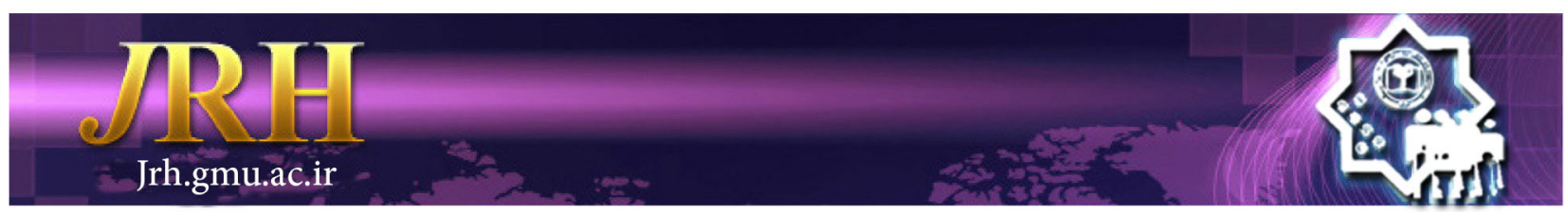

\title{
Acceptance of illness in patients with incurable diseases a qualitative study
}

Bibi Aghdas Asghari ${ }^{1}$, Sedighe Arabi ${ }^{2}$

\author{
Journal of Research \& Health \\ Social Development \& Health Promotion \\ Research Center \\ Vol. 9, No. 5, Sep \& Oct 2019 \\ Pages: $443-453$ \\ DOI: $10.29252 / j r h .9 .5 .443$ \\ Original Article
}

1. Department of Social Sciences, School of Humanities, Islamic Azad University Gonabad Branch, Gonabad, Iran

2. Correspondence to: Department of Social Sciences, School of Humanities, Islamic Azad University Gonabad Branch; Social Development \& Health Promotion Research Center, Gonabad University of Medical Sciences, Gonabad, Iran

Email: sedighe.arabi@yahoo.com

Received: 20 Oct 2018

Accepted: 13 Jan 2019

How to cite this article: Asghari BA, Arabi S. Acceptance of Illness in Patients with Incurable Diseases a qualitative study. $J$ Research Health2019; 9(5): 443- 453

\begin{abstract}
There are many psychiatric consequences of severe and debilitating diseases. Psychiatric disorders are therefore commonly present after a physical illness. The purpose of this study was to investigate the process of acceptance of illness in patients with incurable diseases. The conceptual research framework was based on Kübler-Ross's theory of acceptance of illness. In this qualitative research, a guided approach to content analysis has been used. This study was carried out using semi structured interviews based on theoretical saturation with 15 patients with incurable diseases. The results of this study have shown that patients with incurable diseases have passed seven stages of death acceptance: shock disease, coping strategies, disease denial, anger, depression, referral group reactions, and acceptance of illness. Considering the need to recognize the process of accepting the disease in patients with incurable disease, the results of this study may be useful for those patients involved in treating the disease correctly. Furthermore, the results of this study can be used by researchers, managers, and planners to enhance their knowledge of incurable patient needs and evidence-based planning.
\end{abstract}

Keywords: Acceptance, Diseases, Incurable, Process

\section{Introduction}

The desire of the man for immortality causes many physical and psychological injuries to a dying person. Death has been marginalized in today's modern age. Nevertheless, this fact must inevitably be addressed and models for thinking about it must be provided to communities, particularly patients and people with incurable diseases [1].

Individuals with incurable diseases include a group that is exposed to death-induced anxiety, and cancer is one such disease. In Iran, cancer is the third leading cause of death after cardiovascular disease and accidents. Cancer currently accounts for more than $12 \%$ of deaths in both the globe and Iran. There are two types of pain incurable patients at the same time. The first is the physical disease's pain and the second is the psychological disorder's pain. Today, medical science has made a lot of progress in reducing these patients' physical pain, but it is unclear how to deal with these patients' psychological suffering due to their complex nature [2].

Some of the reasons for these problems are due to the subjective meanings of cancer diagnosis in the minds of the patient and his or her family, 
such as the likelihood of misconduct, pain, financial and social deficiencies, dependence, family structure fracture, death and death, and the actual event of some of these phenomena in the lives of patients [3].

Studies show that incurable dying patients' psychological suffering is due to the feeling of solitude and meaningless life. Even when thinking about it, many people are afraid of death; death has disturbed their daily lives and created a sense of insecurity and psychological distress in them. Nevertheless, the reality of death will be accepted by others. Studies have shown that between $50 \%$ and $85 \%$ of patients with cancer have a psychiatric disorder at the same time [4].

In a study, Masoudi et al. pointed to the high prevalence of depression and anxiety in patients with incurable diseases that could have consequences such as impairment of treatment, non-use of medicines and lack of dietary adherence that would deteriorate their quality of life [5].

Dehghani et al. reported in a study that future uncertainty and the treatment process are among the most stressful aspects of incurable diseases affecting the patient's hope [6].

Attitudes and fear of death appear to include end of life stress and anxiety. There are five stages of grief, according to Kübler-Ross, when a person faces a terminal disease or any crisis in his life, including; 1) Shock and denial, 2) Anger, 3) Bargaining, 4) Depression and 5) Acceptance. Since its launch, this theory has been widely criticized in many respects, including lack of attention to previous death research, ambiguity in the five stages, limitation of the infor-mation gathering method, lack of attention to individual differences, and environmental impact on individuals. Despite the criticism, KüblerRoss theory has had a significant impact on studies and debatable studies, and researchers, including Jankowska in 2016, have carried out a great deal of research, each addressing specific dimensions of the topic and reporting different results [7].

Given the high rates of incurable diseases in Iran, in particular cancer and the deaths of
49,000 Iranian cancer patients in 2015 [8] and the doubling of cancer deaths in Iran between 1990 and 2015, it is hoped that effective interventions can be made using empirical concepts and knowledge for clinical populations to facilitate acceptance of illness. This is because diseasebased treatment is one of the therapeutic patterns that can be effective in reducing depression and improving the quality of life of patients and expanding new horizons for patients with incurable diseases [9].

Since no study has fully investigated the process of acceptance of illness in patients with incurable diseases in the country to the best of our knowledge, the present study aimed at investigating the process of acceptance of illness in terminal disease patients.

\section{Method}

Using individual and semi structured interviews with 15 patients with incurable disease in Gonabad city, Northeast of Iran, the study used a direct content analysis and conducted theoretical saturation. In the qualitative field study, the sampling method is purposeful or theoretical sampling. Data analysis was conducted simultaneously with the collection of data using guided qualitative content analysis.

Theoretical sampling in such research is based on the concepts that emerge during the analysis. The number of people interviewed, i.e. the sample size, depends on questions being theoretically saturated, so that when the researcher concludes that the responses are given or interviews with informed persons are similar to each other to the extent that no new data emerge [10], the interviews are terminated. The study population included incurable disease patients referring to Gonabad city's health centers in 2017-2018.

A telephone call with several surgeons and cancer specialists was made to select participants. Three of the surgeons were willing to cooperate and introduced the sample to their patients. Some of the other patents have been selected from the health centers. To 
obtain their consent for interviews, the patients were contacted by phone call. Participants were incurable disease patients in the age range of 16-63 years for one to five years. The sample consisted of units with different treatment processes and time of affliction in order to interpret the results more accurately and we also tried to interview people from different groups, including gender, disease type, economic and social status, occupation, education, and children. Because the selecting people as heterogeneous is the best for interviews to avoid similar responses and achieve diverse concepts. Fifteen patients with incurable dis-eases were selected, including eight cancer patients, two the Human Immunodeficiency Viruses (HIV) patients, three Multiple Sclerosis (MS) patients, one dialysis patient and one hemophilia patient using the theoretical sampling method, and interviewed individually.

The data were collected in the present study through semi structured interviews based on the patients ' general condition. The interviews were conducted over a quarterly period in Gonabad. Theoretical saturation has been achieved after 15 interviews, meaning the responses have been repeated and no new ideas have been raised. We explained that information would remain confidential at the beginning of each interview and that interviews would be used for research purposes. The interviews were conducted by a single person and lasted about 25 to 140 minutes. The interviews were recorded and the voice was not recorded by only one person; the interview was therefore noted. Each interview started with questions such as age, occupation, and so on about demographic information.

General questions were then asked, including what were your disease's early signs? After the first signs of the disease and before referring to a doctor, what did you think about your disease? What was your reaction to the diagnosis of your disease? How did you behave during the illness by your circles (referral groups)? How do you think about your current living conditions and interpersonal relationships? All participants' voices were recorded with their consent and immediately transcribed. They were then analyzed using the analysis of the directed content.

The purpose of the guided content analysis is to validate a conceptual framework or theory or possibly develop it implicitly. In this type of study, the theory chosen can help focus on the research issue. The theory, on the other hand, can help to predict interesting variables or relationships among variables. Shannon and Hsieh presented this approach in 2005 [11]. There are three stages of preparation, organization and reporting for the analytical content analysis. In the preparation phase, each interview is read several times to immerse data after transcribing the interviews. The researchers then formed a background matrix in the organizational process to allow the disclosure of the new main categories. The data are repeatedly reviewed to disclose concepts matching predefined classes and assigned to find content that was or might have been an exemplary example for them.

In this way, coding was done for other semantic units that were not related to the main classes but related to selfesteem, and then these classes could be placed in the matrix or the formation of new major classes based on the conceptual and logical connection. Member check used a permanent and ongoing approach to conflict with the research subject to ensure the credibility of the findings.

The method used to provide verification or objectivity by the observer review. We tried to use a wide range of contributors to ensure transferability in terms of sex, type of disease, age, education, and occupation. In order to comply with the ethical principles of research and participants ' rights, an introductory letter was submitted after obtaining research approval from the Research Ethics Committee to obtain permission from hospital and health center authorities, identify qualified participants and give their informed consent. Furthermore, the researcher emphasized the right to withdraw from the study at any stage and the anonymity and confidentiality of the information [12].

Fifteen participants were interviewed in this study, including eight cancer patients, 
two HIV patients, three MS patients, one dialysis patient, and one hemophilia patient. $53.3 \%$ female participants and $46.7 \%$ male participants. The age range of participants was 16-63. Data analysis resulted in the extraction of 375 primary codes, all categorized into 7 sub-classes, including shock therapy, coping strategies, denial and denial of disease, anger, depression, the response of referral groups, disease admission as shown in Table 2.

Table 1 A brief profile of patients with incurable diseases

\begin{tabular}{|c|c|c|c|c|c|c|c|}
\hline Name & Disease & Genus & Age & Education & $\begin{array}{l}\text { Marital } \\
\text { status }\end{array}$ & Job & $\begin{array}{l}\text { Number of } \\
\text { children }\end{array}$ \\
\hline Participant 1 & Thyroid cancer & Female & 31 & $\begin{array}{c}\text { Bachelor of } \\
\text { Arts }\end{array}$ & Married & Employee & 1 \\
\hline Participant 2 & Breast cancer & Female & 61 & Intermediate & Married & Housewife & 6 \\
\hline Participant 3 & $\begin{array}{l}\text { Breast cancer and } \\
\text { brain tumor }\end{array}$ & Female & 34 & $\begin{array}{c}\text { Bachelor of } \\
\text { Arts }\end{array}$ & Married & Housewife & 2 \\
\hline Participant 4 & Lymphatic cancer & Male & 39 & $\begin{array}{l}\text { Master of } \\
\text { Science }\end{array}$ & Married & Employee & 3 \\
\hline Participant 5 & HIV & Male & 22 & Intermediate & Single & Unemployed & 0 \\
\hline Participant 6 & Hemophilia & Male & 33 & Diploma & Married & Driver & 2 \\
\hline Participant 7 & $\begin{array}{l}\text { Uterine and lymph } \\
\text { nodes cancer }\end{array}$ & Female & 45 & $\begin{array}{l}\text { Bachelor of } \\
\text { Arts }\end{array}$ & Married & Housewife & 2 \\
\hline Participant 8 & Brain tumor & Male & 43 & Diploma & Married & Plumber & 2 \\
\hline Participant 9 & MS & Female & 32 & Diploma & Married & Housewife & 2 \\
\hline Participant 10 & HIV & Female & 45 & Diploma & Divorced & Housewife & 0 \\
\hline Participant 11 & MS & Male & 32 & $\begin{array}{l}\text { Associate } \\
\text { Degree }\end{array}$ & Single & $\begin{array}{c}\text { Network } \\
\text { worker }\end{array}$ & 0 \\
\hline Participant 12 & MS & Male & 53 & $\begin{array}{c}\text { Bachelor of } \\
\text { Arts }\end{array}$ & Married & Employee & 3 \\
\hline Participant 13 & Leukemia & Female & 50 & $\begin{array}{c}\text { Bachelor of } \\
\text { Arts }\end{array}$ & Married & Employee & 3 \\
\hline Participant 14 & Bladder cancer & Female & 63 & Illiterate & Married & Housewife & 5 \\
\hline Participant 15 & Dialysis & Male & 16 & Intermediate & Single & Unemployed & 0 \\
\hline
\end{tabular}

Shock of disease: The stage of disease shock was the first stage to which patients were exposed. At this stage, the patient does not believe that a severe illness has affected him. The shock of the disease has been caused in the present study by factors such as type of disease, loss of beauty, and fear of remission of the disease. This increases family emotional issues and paves the way for communication problems [13]. Participant 1: "When I heard that I had thyroid cancer, I was overwhelmed by the term cancer, and it didn't go out of my head."

Coping strategies: After the shock stage, the patients started to work on strategies to cope with their relaxation, including searching the Internet, asking for available doctors, appealing to God and the Imams, and addressing spirituality, apparent beauty to prevent rejection, writing wills and asking for forgiveness and drug therapy. Participant 3: "I came to God and I said he made me patient, that is, the resort is the only factor in my success, and he really helped and resorted to somebody who is a myth."

Denial of Illness: The denial stage was created by the suspicion and unbelief of the patient [13]. At this stage, by denying the disease, the patient tries to maintain its mental condition. Participant 4: "I don't think I'm having this disease. I do all the exercises and three older children, very little does not seem to be drinking my face to my age and wells have this disease.

Anger: Anger is a step observed after coping strategies in this study. Where the patient searched for guilty. When the denial wall collapses, denial gives way to anger, jealousy and hate, and patient anger refers to the environment without any regularity. Participant 3: " I went to the health center and they knew that my family had breast cancer and they gave me the pills and nobody told me they didn't eat those pills." 
Table 2 Validity Stages of the Acceptance Process

\begin{tabular}{|c|c|c|c|}
\hline Row & Primary sub-concepts & $\begin{array}{l}\text { Secondary sub- } \\
\text { concepts }\end{array}$ & Concepts \\
\hline \multirow[b]{3}{*}{1} & Hearing cancer name, tumors, multiple sclerosis, diabetes-related leg amputation & Type of disease & \multirow{3}{*}{$\begin{array}{l}\text { Shock of } \\
\text { disease }\end{array}$} \\
\hline & $\begin{array}{l}\text { Loss of hair after chemotherapy, loss of skin after operation, amputation of the legs and } \\
\text { defects }\end{array}$ & Loss of beauty & \\
\hline & $\begin{array}{l}\text { Successive scanning and fear of involving other parts of the body, completion of breast } \\
\text { radiation therapy and fear of re-radiation therapy after brain tumor, three-month check-ups } \\
\text { after six months, successive surgery prescribed by the doctor, momentary touch of the } \\
\text { body on the bed, and fear of recurrence of disease }\end{array}$ & $\begin{array}{l}\text { Fear of disease } \\
\text { recurrence }\end{array}$ & \\
\hline 2 & $\begin{array}{l}\text { Searching the Internet and seeking available physicians, recourse to God and praying and } \\
\text { addressing spirituality, physical embellishment to prevent others from refusing, writing } \\
\text { wills and seeking forgiveness, self-mutilation, drug therapy }\end{array}$ & Looking for Calm & $\begin{array}{l}\text { Coping } \\
\text { Strategies }\end{array}$ \\
\hline 3 & $\begin{array}{l}\text { Testing frequently, no, I'm not sick, I'm an athlete, immune to diseases, I don't believe the } \\
\text { diseases, I visit several doctors }\end{array}$ & Suspicion for disease & $\begin{array}{l}\text { Denial of } \\
\text { Illness }\end{array}$ \\
\hline 4 & $\begin{array}{l}\text { End the happiness of the period of commitment, failure of medical staff, separation from } \\
\text { peers }\end{array}$ & Finding a guilt & Anger \\
\hline \multirow[b]{2}{*}{5} & Desperation for recovery and healing, willingness to die & Procurement & \multirow[b]{2}{*}{ Depression } \\
\hline & $\begin{array}{l}\text { Negative-thinking patients, crying for hair loss, various disturbances and seeing the } \\
\text { family's grief, seeing the doctor's private limbs, disability and retirement, losing beauty } \\
\text { and bad physical condition, type of illness, family burden, shy and isolated }\end{array}$ & Reactive & \\
\hline \multirow{8}{*}{6} & $\begin{array}{l}\text { Family charity, prohibiting housekeeping, praying with family and friends, helping family } \\
\text { and friends to prepare food for the patient, accompanying the patient with surrenders while } \\
\text { walking, weeping with family and friends }\end{array}$ & Feeling of Pity & \multirow{2}{*}{$\begin{array}{l}\text { Positive } \\
\text { reaction of } \\
\text { referral groups }\end{array}$} \\
\hline & $\begin{array}{l}\text { Comfort and well-being of patients from family, moral and material support by family } \\
\text { and friends, ensuring patient care costs, physician support, optimistic clips and high-spirit } \\
\text { patients, spousal support, positive counseling, inviting patients to be patient }\end{array}$ & Positive Thinking & \\
\hline & $\begin{array}{l}\text { Hiding the patient's spouse's disease from his / her family, getting Polo dressed for } \\
\text { children after thyroid surgery, hiding the disease from the doctor, fear of other people's } \\
\text { negative feelings, the patient's condition from his / her family, hiding sick family members }\end{array}$ & Secrecy and coverup & \multirow{6}{*}{$\begin{array}{l}\text { Negative } \\
\text { reaction of } \\
\text { referral groups }\end{array}$} \\
\hline & $\begin{array}{l}\text { Fellowship with cancer and expression of recovery, responsibility for failure of patients } \\
\text { at home, predict recurrence of diseases by doctors and medical staff and sometimes react } \\
\text { husband and cry after diagnosis wife, chemotherapy and Skip's beautiful wife's concern, } \\
\text { People humiliated because of Hairless part of the patient after surgery, tumor, quiet family } \\
\text { next to the patient, parents grieved because of children's disease, doctor's reply, people's } \\
\text { insult to the patient because of prolonged illness }\end{array}$ & Anxiety and Despair & \\
\hline & $\begin{array}{l}\text { Exemptions from military service, lack of employment in state organs, prohibition of } \\
\text { heavy work, neglect of a spouse, physical and spiritual abandonment of the patient and his } \\
\text { family due to the lack of hope of recovery, dismissal from work }\end{array}$ & $\begin{array}{l}\text { Social exclusion due } \\
\text { to physical disability }\end{array}$ & \\
\hline & $\begin{array}{l}\text { Cut the patient's family and friends, sit away from the patient, separate the patient's place } \\
\text { of rest, drop the test page in front of the patient. }\end{array}$ & $\begin{array}{l}\text { Social exclusion due } \\
\text { to the fear of transfer }\end{array}$ & \\
\hline & $\begin{array}{l}\text { Contemptuous look in the laboratory, parents ' physical punishment, staying away from } \\
\text { sick villagers, prostitutes counting patients and relatives }\end{array}$ & $\begin{array}{l}\text { Social exclusion due } \\
\text { to moral immorality } \\
\text { and leakage }\end{array}$ & \\
\hline & $\begin{array}{l}\text { To avoid patients during therapy (iodine therapy) by family and medical staff, lack of } \\
\text { presence in public places up to a week, stay away from pregnant women and children up to } \\
\text { a week, separate all food containers a week, use the arrows tank after urination away from } \\
\text { all people a week, humiliated by others }\end{array}$ & $\begin{array}{l}\text { Social exclusion due } \\
\text { to special treatments }\end{array}$ & \\
\hline \multirow{3}{*}{7} & $\begin{array}{l}\text { All men are mortal destiny and God of the future and immortal, give appreciation, world of } \\
\text { testing and testing, patient and not against the Lord }\end{array}$ & $\begin{array}{l}\text { Acceptance of } \\
\text { independence }\end{array}$ & \multirow{3}{*}{$\begin{array}{l}\text { Acceptance of } \\
\text { illness }\end{array}$} \\
\hline & Birth and lifespan, concern for his wife and children's future & $\begin{array}{l}\text { Acceptance of } \\
\text { responsibility }\end{array}$ & \\
\hline & $\begin{array}{l}\text { Addressing people's rights and asking forgiveness from the offended, blaming his wife and } \\
\text { lack of understanding at the time of illness (the Lord's illness flip), When you were happy, } \\
\text { you thought about the future, the patient examination of the Lord and the reason for the sin } \\
\text { of lightness, suffering worldly from sins. }\end{array}$ & $\begin{array}{l}\text { Feeling of guilty } \\
\text { (self-guilty) }\end{array}$ & \\
\hline
\end{tabular}


Depression: The patient eventually finds the need for surgery and prolonged hospitalization after the high stages, and she gradually shows signs of illness. The patient can no longer deny her illness at this stage, and her feelings of wrath and anger give her a sense of deterioration and depression. Depression, of course, often comes with feelings and behaviours, including feelings of injury and loss, failure, despair and joy, helplessness, senselessness and emptiness, pessimism for the future, reduced selfesteem and a sense of worthlessness and inefficiency [14].

A: First, it's a reaction to depression. The result of losing something in the past is this type of depression. The causes of this depression include loss of ability, amputation, and impaired family conditions. Participant 9: "For anyone I've been fired from my job. I don't want to talk."

B: The patient's prepared or preliminary depression ready to accept death. This form of depression, unlike depression, is an answer to the problem. Your patient is willing to lose everything at this stage. The patient is actually trying to facilitate the acceptance of death at this stage. Participant 7: "Live or die, I don't care and that's how I marked my life. I'm waiting for my life to come to an end. I'm not afraid that death will bring Doom for how long. Most were seeking forgiveness."

Reaction of referral groups: It is very important to respond to referral groups at all stages of admission of illpatient disease. The patient's firstdegree relatives and firstdegree relatives who spend more time experiencing different reactions to the patient, classified into the following two categories:

A: Referral groups such as compassion and optimism for positive reaction. "Children Hamm help me out so much. My brothers and sisters kept people hitting me head."

B: Special treatment was given to adverse reactions such as referral groups of secrecy and coverup, anxiety and despair, social exclusion due to physical disability, social exclusion and stigmatization due to fear of transmission through other stages of moral and social exclusion. Participant 9 "So that's bad news for me. All the neighbors said we heard that the human side of MS was paralyzed. People are looking at the bad guy in particular. Because they believe other people are unable to paralyze the field, and certainly in the future. I think MS is sick and looked pretty human, my owner threw me out. "

Acceptance of illness: The process of accepting the disease takes place after this stage. Last stage of the acceptance of illness or wall is that patients are forced to confront it and face the stage a person has accepted their disease. It appears that older people are more mature psychosocially than young people and make death easier and easier [15]. Patients were prepared and accepted with their disease in three forms in this study.

A: Acceptance of autonomy derived from belief in God and divine patient trials. Participant 4: "I believe in the world of testing and testing when they say this world, and I praise God."

B: Responsibility acceptance: an admission created by life responsibilities such as childbirth and patient fellowship. Participant 1: "I am living it. Oh, what a sin my wife and children are doing."

$\mathrm{C}$ : Acceptance of illness as a punishment for the actions: in the past, the patient is considered to be the subject of the disease in this type of admission for committing sins. Participant 4: "One of the reasons I think has affected me is because my wife and I don't understand myself most of the time. Say the ceasehouse constantly and do not exercise headache like I do to stay healthy."

\section{Discussion}

Kübler-Ross's theory significant impact on the study and discussion of death and approach to death is so bad that the Kübler-Ross's largest contemporary death is so bad. But the idea of raising the reviews considerably up to now among them, the lack of attention to individual differences and the impact of the environment on individuals and the like can be mentioned. In his studies based on empirical observations, Kübler-Ross claimed patients on the brink of death could accept 
their death during their 5-step process.

These stages are denial, anger, negotiation, depression, and ultimately acceptance of illness. Kübler-Ross, the 5 stages of building and defending human exposure to harsh conditions introduces and explains that although these steps are considered separate, they often overlap [12]. In this study, patients dying in a 7-step process to accept his death that these steps are: shock disease, coping strategies, denial of disease, anger, depression (breaking society's isolation), referred to by the Response group, disease acceptance.

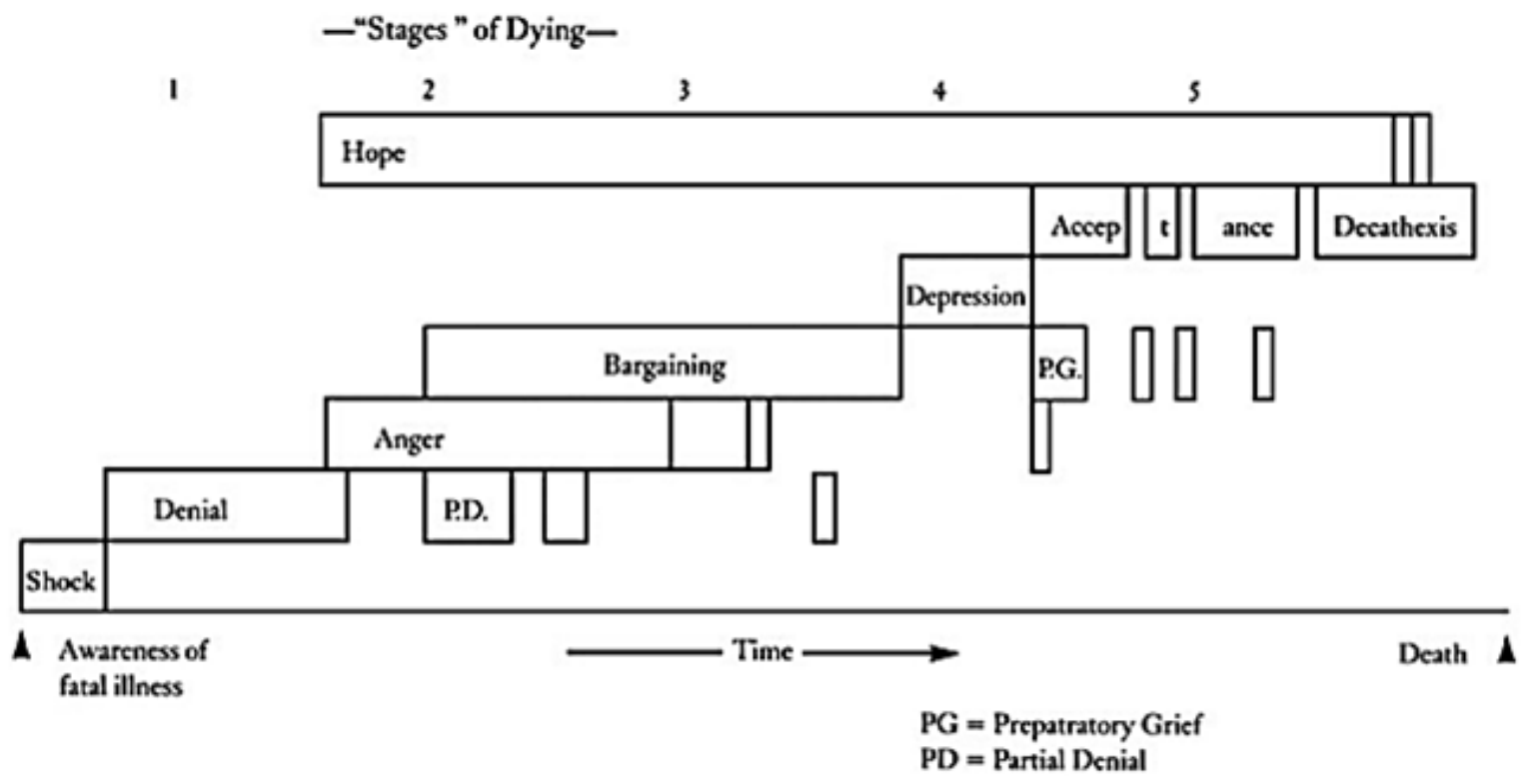

Figure 1 Procedure for acceptance of death, according to Kübler-Ross's

According to Kübler-Ross's (Figure 1) stages of dying study include The shock stage, which was also observed in the Kübler-Ross's model, was the first stage in which patients were exposed in the present study, but Kübler-Ross did not list it in five main stages. The shock of the disease was caused in the present study by factors such as the type of disease, the loss of beauty and the fear of disease returning. This increased the family's emotional problems and communication issues [13].

Emotion plays an important role in adapting as an important determinant to stressful life events. After the shock, the patients started to work on strategies to cope with their relaxation, including access to the Internet, seeking available doctors, appealing to God and the imams, and addressing spirituality, apparent beauty to prevent rejection, writing wills and seeking crying and drug therapy. One of the common stages between the present study and the study by Kübler-Ross is the stage of denial, which was created by patients due to doubt and belief in illness. Kübler-Ross believed that man makes his death impossible in his unconscious.

That's why we face death one day almost unimaginable. Thus, in the face of news of the deadly disease, the first stage is denial. The patient is trying to maintain its denial mood disorders at this stage. Kübler-Ross believed that in all patients, whether those who are explicitly aware of their disease or those who have indirectly identified this issue, these stages are seen on the verge of death.

If all people are afraid of death, the KüblerRoss caught a community, the nation had to defend itself in ways that were ultimately destructive. In his opinion, a person must consciously accept his death in the process of dying so that he can attain some kind of immortality. Human beings are paying a high price with denial of death, including limiting our inner life, dimming our vision and destroying our rationality, which is ultimately self-deception. 
Kübler-Ross knows a number of factors that affect the denial of death attitude, but one of the major causes of death in modern societies denies the medical industry's development. Through these sciences, death, which until recently was explained only by religious passages, was defined and its diminutive aspect diminished. Indeed, before his death he knew God's will and religion was the sole source of death justification. But progress in the biomedical definition of death as an accident and the role of religious declarations in the interpretation of death has disappeared.

Another factor that affects Western societies' denial of death is secularism and religious beliefs as well as modernity's progress. Modern societies are becoming increasingly secularized and people in these societies are not interpreting life's phenomena in the religious context.

Another factor affecting the denial of death of Western societies undermines secularism and religious beliefs as well as the progress of modernity. Modern societies become more and more secularized and people in these societies do not interpret the phenomena of life in the religious context [15].

Other factors also affect the denial of death and the illness of modern societies ' movement towards personal and personal life. For their painful moments, the lack of emotional relationships makes people unsupporting. Death is one of the moments and perhaps the hardest, so sickness is a person who sees himself as helpless in dealing with this problem. Denial of death[16] and finally, rationalizing the issue of death is the last factor. Because death in modern societies is affected by many of these countries' regulatory phenomena and administrative processes, and its emotional aspects have been severely diminished.

This resulted in the process of industrialization being buried in Western countries today so that all funeral and burial are the companies [17]. As is known, burial and burial establishments also reinforce denial of death and attempt to show that death in the life of a person has no real truth.

Anger is a step observed after coping strategies in this study. Where the patient searched for guilty, our study and Kübler-Ross share this step. Kübler-Ross believes that the wall of denial collapses at the end of the first phase, denying its place to anger, jealousy and hate, and that the patient removes his anger from his environment without regularity. All causes the patient to be dissatisfied in this situation. Anger can be considered as an integral part of the dying process at this stage. In the sense that all types of communication appear dark and boring in a medical setting for a dying patient $[1,14]$.

Dialog is a stage that our patients do not clearly state in our study, but it can be seen from the efforts of patients to treat and pray and mention God that most patients are trying to survive. Kübler-Ross believed it's difficult and difficult to study this stage because it often happens between the patient and the Lord. The patient keeps a secret most of the promises and promises with God but sometimes refers to them in private interviews. His life to God, so many times patients to recovery [18]. Eventually, the patient finds the need for surgery and prolonged hospitalization after the high stages, and she is gradually showing signs of illness. The patient can no longer deny her illness at this stage, and her feelings of wrath and anger give her a sense of deteriora-tion and depression. Depression, of course, often comes with feelings and behaviors, in. cluding feelings of injury and loss, failure, despair and joy, helplessness, senselessness and emptiness, pessimism towards the future, decreased selfesteem, and a sense of worthlessness and inefficiency. These conditions exacerbate the disease's psychological and physical symptoms, and the patient has panic and anxiety [19].

The sick person, the mentally vulnerable person and the cause of psychiatric disorders such as depression in these circumstances [14].

The Kübler-Ross distinguishes between two types of depression and believes that depression patients need to distinguish between two types of depression. The first 
depressive type is reaction. This kind of depression in the past is the loss of something. Loss of strength, amputation, and family disruption include the possible causes of this depression. But other depression type is primary or provides the patient with readiness to accept death. This type of depression is due to the problems ahead, unlike reactive depression. The patient is preparing to lose everything at this point. The patient is actually trying to facilitate the acceptance of death at this stage, and these stages (logistical and reactive) are very consistent with our study. Furthermore, the positive reactions of referral groups such as pity and positive thinking, and the negative reactions of referral groups such as coverup and coverup, anxiety and desperation, social exclusion due to physical disability, social exclusion due to fear of transference, moral exclusion and refusal. The social status was due to specific therapies from a different stage, followed by the stage of depression in our study but not considered in the study by Kübler-Ross. The process of accepting the disease takes place after this stage. acceptance of illness, a common phase between the current study and Kübler-Ross's study, is the final stage or wall patients inevitably face and face $[14,15]$. According to Kobler, at this stage, the patient is not depression and not angry. Of course, this stage should not be suspected of being a happy stage, but it is an empty period of any emotion. The acceptance stage is considered a valuable step in the Kübler-Ross's theory. Accepting the disease in this study involves accepting independence, accepting responsibility, and accepting the disease as a punishment for acts that appear to be guilty. Using the concept of stage seems to mean the existence of a regular set of states and feelings that can apply to all patients exactly.

It should be noted that after reaching the admission stage, many patients may return to the preceding stages. In addition to the KüblerRoss's process, patients experienced a series of steps in the current study. While these steps are presented separately, in many cases they overlap. There's also an element of hope in all these steps. However, in the face of harsh conditions and disastrous news, these steps are a human defense mechanism. It seems that the type of people's emotional reactions to death and their acceptance depend entirely on actions, behavior, thoughts, personality structure, and ability to cope with past life issues and problems [20]. On the other hand, it depends on the age, gender, living conditions of the patient, and how people live $[21,22]$ to feel, believe, and accept a disease. Individual differences and lifestyle factors are therefore factors that in two studies can lead to differences. On the other hand, in the West and the United States, the culture of facing death varies with our society. The other reason for the difference between the two studies can therefore be attributed to a different society and the different nature of the disease.

According to Kübler-Ross, the diagram below shows the stages of death acceptance in this study.

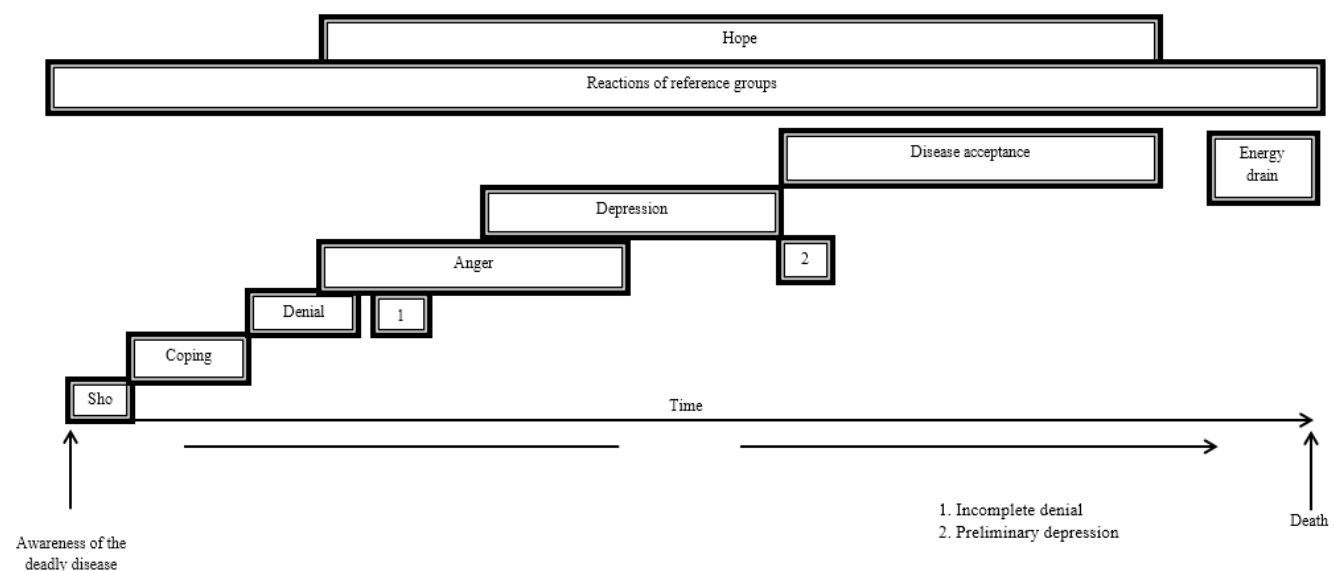

Figure 2 The acceptance of our patients, according to Kübler-Ross 
Like all qualitative studies, this research limits the generalizability of the results and suggested that the research should be conducted under distinct circumstances and cultural conditions

\section{Conclusion}

Because of the need to recognize the process of accepting the disease in patients with severe obstructive diseases, the results of this study can be useful in dealing with those patients. Researchers, managers and planners can also use the results of this study to better understand the needs of patients with severe and progressive and evidencebased planning. Since understanding the experiences, perceptions and needs of patients with severe illnesses has a potential value in the disease care system, the results of this study can help prioritize the care and treatment of patients with diabetes.

\section{Acknowledgments}

The author wishes to express his appreciation of all the participants.

\section{Authors' contributions}

Study design: BAA, SA

Data collection: SA, BAA, MS

Manuscript preparation: SA

All authors have read and approved the final version.

\section{Conflict of Interest}

"The author declares that they have no competing interest"

\section{Funding}

The author (s) received no financial for the research authorship and/or publication of manuscript.

\section{Availability of data and materials}

The datasets used and/or analyzed during this study are available from the corresponding author on reasonable request.

\section{References \\ 1- Ghaseminia P, Ranjbar Ghadim NS. Psychology of death. Journal of New Advances in Behavioral Sciences2017; 9(2): 50-63.}

2- Ghazavi ST. The grounds for the death anxiety and the prevention of it in the teachings of Islam. Biquarterly Journal of Islamic Education2011; 11(5): 173-94.

3- Malekian A, Alizadeh A, Ahmadzadeh GH. Anxiety and depression in cancer patients. $J$ Res Behavior Sci2007; 5: 115-8.

4- Akechi T, Okuyama T, Akizuki N, et al. Course of psychological distress and its predictors in advanced non-small cell lung cancer patients. Psychooncology2006; 15(6): 463-73.

5- Masoudi Alavi N, Sharifi Kh, Aliakbarzadeh Z. Depression and anxiety in patients undertaken renal replacement therapy in Kashan during 2008. Feyz: (Journal of Kashan University of Medical Sciences)2009; 4(12): 46-51.

6- Dehghani Y. The effectiveness of acceptance and commitment group therapy on depression and quality of life in women with dialysis patients. Journal of Clinical Psychology2016; 3(8): 1-11.

7- Jankowska-Polańska B, Kasprzyk M, Chudiak A, Uchmanowicz I. Effect of disease acceptance on quality of life in patients with chronic obstructive pulmonary disease (COPD). Pneumonol Alergol Pol2016; 84(1): 3-10.

8- Larizadeh M, Malekpour-Afshar R. Knowledge of patients with cancer towards their disease status. Research in Medicine2007; 31(1): 85-90

9- Hor M, Aghaei A, Abedi A, Attari A. The effectiveness of acceptance and commitment therapy on depression in patients with type 2 diabetes. J Res Behav Sci2013; 11(2): 121-8.

10- Mollayousefi M, Bagheri MR. The modern human and the Problem of death: a study of Elisabeth KublerRoss' Theory. Journal of Religious Studies2018; 20(10): 133-50.

11- Barrera M Jr, Toobert DJ, Angell KL, Glasgow RE, MacKinnon DP. Social support and social-ecological resources as mediators of lifestyle intervention effects for type 2 diabetes. J Health Psychol2006; 11(3): 483-95.

12- Ebrahimi Belil F, Alhani F, Ebadi A, Kazemnejad A. Explaining the concept of selfesteem in patients with chronic conditions based on the family-centered empowerment model: A directed content analysis. Iranian Journal of Psychiatric Nursing2017; 2(5): 23-30. 13- Mousavi Diva R, Moghadamfar N, Amani O. Evaluating family functioning and spiritual health in women with breast cancer, cancer-treated and healthy women. Iranian Journal of Psychiatric Nursing (IJPN)2017; 5(5): 49-56.

14- Bahrami N, Moradi M, Soleimani MA, Kalantari Z, Hosseini F. Death anxiety and its relationship with quality of life in women with cancer. Iran Journal of Nursing (IJN)2013; 26(82): 51-61.

16- Bahrami M, Mosavizadeh SR, Ahmadi Faraz MM, 
Shirvani A. Concerns of Iranian Muslim pa-tients suffered from cancer in the last stages of life: A qualitative study. Journal of Clinical Nursing and Midwifery2017; 6(4): 32-41.

17- Fathi M, Sanagoo A, Jouybari L, Yazarloo M, Sharif Nia H. Death anxiety in hemodialysis patients admitted to Panj-Azar teaching hospital, 2013. Journal of Research Development in Nursing and Midwifery2016; 12(3): 48-55. 18- Moeini M. Patients' religious beliefs in cardiac pain situations: A Qualitative Research. Journal of Qualitative Research in Health Sciences 2014; 3(1): 104-13. 19- Audrey B, Kozier B. Kozier \& Erb's fundamentals of nursing: concepts, process, and practice, 10th Edition, Libraries Australia, Upper Saddle River, NJ: Pearson Prentice Hall; 2008.

20- Janbabaei Gh, Hesamzadeh A, Esmaeili R. A review of approaches for disclosing cancer diagnosis to the patients. Journal of Clinical Excellence2014; 3(1): 12-28

21- Norton TR, Monne SL, Rubin S, et al. Prevalence and predictors of psychological distress among women with ovarian cancer. J Clin Oncol2004; 5(22): 919-26.

22- Seale C. Media constructions of dying alone: A form of 'bad death'. Soc Sci Med2004; 58(5): 967-74.

Copyright(C) 2016 ASP Ins. This open-access article is published under the terms of the Creative Commons Attribution-NonCommercial 4.0 International License which permits Share (copy and redistribute the material in any medium or format) and Adapt (remix, transform, and build upon the material) under the Attribution-NonCommercial terms. 